\title{
The Immigration Reform and Control Act of 1986
}

\author{
DANIEL E. LUNGREN*
}

On November 6, 1986, President Reagan signed into law the Immigration Reform and Control Act of 1986 (IRCA). This legislation was completed by Congress one day before the 99 th Congress adjourned. This Article will discuss previous legislative attempts to control immigration and the evolution of this comprehensive immigration reform bill. Major provisions that Congressman Lungren believes are integral to comprehensive immigration reform legislation will be highlighted.

\section{Previous United States Legislative Efforts to Craft IMMIGRATION REFORM}

Legislation to control illegal or undocumented immigration dates back to the early 1950 's. ${ }^{1}$ Attempts to pass legislation prohibiting employment and establishing penalties for the harboring of undocumented aliens back in 1951 and 1952 were only partially successful. ${ }^{2}$ The Act of March 20,1952, subsequently recodified as sections 274 and 287(a)(3) of the Immigration and Nationality Act of 1952, made the willful importation, transportation, or harboring of undocumented aliens a felony, punishable by a $\$ 2000$ fine or imprisonment of up to five years, or both. ${ }^{3}$ However, employment was specifi-

* United States Representative from Long Beach, California. B.A. (cum laude) 1968, University of Notre Dame; J.D. 1971, Georgetown University. Congressman Lungren serves as the ranking minority member on the Subcommittee on Immigration, Refugees and International Law. This Article was prepared with the staff assistance of Margaret Webber, Associate Counsel on the House Committee on the Judiciary.

1. D. Reimers, Recent Immigration Policy: AN ANAlysis 27-29 (1980); H.R. REP. No. 682, 99th Cong., 2d Sess. 51 (1986) [hereinafter House Committee Report].

2. D. ReImERS, supra note 1, at 27-29; see also House Committee Report, supra note 1 , at 51 .

3. Immigration and Nationality Act $\S 274,8$ U.S.C. $\S 1324(a)$ (1982) [herein- 
cally exempted from the penalties for harboring in what was popularly referred to as the "Texas proviso."

The House Judiciary Subcommittee, with special jurisdiction over immigration matters, held extensive investigative and legislative hearings on the problem of undocumented aliens during the $92 \mathrm{~d}$ Congress beginning in $1971 .{ }^{\circ}$ Subsequently, with the continuous support of the Nixon and Ford Administrations, the House twice passed legislation to penalize the knowing employment of illegal aliens. H.R. 16,188 passed the House during the 92d Congress on September 12,1972 , by voice vote after a motion to recommit it to the Judiciary Committee was defeated. ${ }^{6}$ During the 93d Congress, H.R. 982 passed the House on May 3, 1973. ${ }^{7}$ Neither bill, however, received action by the full Senate.

On January 6,1975, President Ford established the cabinet-level Domestic Council Committee on Illegal Aliens, chaired by Attorney General Edward Levi. ${ }^{8}$ In its December 1976 report, the Domestic Counsel Committee concluded that the major impact of undocumented aliens seemed to be in the labor market; the report recommended enactment of legislation establishing penalties for knowing employment of undocumented aliens as well as enactment of a provision allowing for the regularization of status of certain undocumented aliens. The Committee recommended, among other reforms: (1) that penalties be imposed upon employers who knowingly hire aliens not authorized to work; (2) that the H-2 and other temporary worker programs be reevaluated and streamlined to operate more effectively; and (3) that a humane and practical solution be developed concerning the status of the large number of undocumented aliens already here. ${ }^{\theta}$ Similar proposals were included in legislation and other initiatives forwarded by the Carter Administration in 1977.10

after INA]; see House Committee Report, supra note 1, at 52.

4. INA § 274, 8 U.S.C. § 1324(a); see also Mainland, Counseling Employers Under the New Immigration Act, 7 CAL. LAW., Feb. 1987, at 44; House Committee Report, supra note 1, at 52 .

5. Hearings were held in Washington, D.C., Los Angeles, Denver, El Paso, Chicago, Detroit, and New York. See Illegal Aliens: Hearings Before Subcomm. No. 1 of the House Comm. on the Judiciary, pts. I-V, 92d Cong., 1st \& 2d Sess. (1971-1972).

6. 118 CONG. REC. 30, 186 (1972) (voice vote passage of H.R. 16,188, 92d Cong., $2 d$ Sess. (1972)).

7. 119 CONG. REC. 14,208-09 (1973) (passage of H.R. 982 by vote of 297-263, 93d Cong., 1st Sess. (1973)).

8. See Preliminary Report of the Domestic Council Committee on IlleGal Aliens, Dec. 1976, at 102-12, reprinted in Congressional Research Service, Selected Readings on U.S. Imaigration Policy and Law: A Compendium (Comm. Print 1980) (reprinted at the request of the Senate Comm. on the Judiciary) [hereinafter PRELIMINARY REPORT]; see also House Committee Report, supra note 1 , at 53 .

9. Preliminary Report, supra note 8, at 240-44; House Committee Report, supra note 1 , at 53 .

10. See H.R. 9531, 95th Cong., 1st Sess. (1977); 54 INTERPRETER Releases 28791 (1977); see also House Committee Report, supra note 1, at 53. 
Another enactment of the 95th Congress of relevance to the undocumented alien issue, was the creation of a sixteen-member Select Commission on Immigration and Refugee Policy to conduct a study of immigration and refugee laws, policies, and procedures, and to report its findings to the President with recommendations for legislative and administrative change. ${ }^{11}$

The Select Commission's basic conclusion was that support for legal immigration is threatened by uncontrolled illegal immigration. That conclusion underlies many of the report's recommendations which included enactment of legislation making it illegal to hire undocumented aliens, increasing border and interior enforcement, and legalizing the status of certain aliens illegally present in the United States. ${ }^{12}$

Joint hearings were held on the report and recommendations of the Select Commission on May 5, 6, and 7, 1981, under the chairmanship of Senator Alan K. Simpson (R.-Wyo.) and Congressman Romano Mazzoli (D.-Ky.). These were the first joint congressional hearings on immigration since those held in 1951 on the legislation that was subsequently enacted as the Immigration and Nationality Act of $1952 .{ }^{13}$

Since the Select Commission's recommendations and the joint hearings, comprehensive immigration reform legislation has been considered by the 97 th, ${ }^{14}$ the $98 \mathrm{th}^{18}$ and the $99 \mathrm{th}^{16}$ sessions of Con-

11. Act of October 5, 1978, Pub. L. No. 95-412, § 4, 92 Stat. 907 (1978) (establishing a Select Commission on Immigration and Refugee Policy); see also House Committee Report, supra note 1 , at 53 .

12. See Select Comm'n on Immigration and Refugee Policy, U.S. ImmigraTION POLICY AND THE NATIONAL INTEREST: FINAL RePORT aND ReCOMMENDATIONS OF The Select Comm'N on Immigration and Refugee Policy 59-60 (1981) [hereinafter SELECT COMM'N FINAL REPORT]; Joint Hearings Before the Subcomm. on Immigration and Refugee Policy of the Senate Comm. on the Judiciary and the Subcomm. of Immigration, Refugees, and International Law of the House Comm. on the Judiciary 4 (1981) (Opening statement of Sen. Alan K. Simpson) [hereinafter Joint Hearings]; see also House Committee Report, supra note 1, at 53.

13. Joint Hearings, supra note 12, at 2.

14. See S. 2222, 97th Cong., 2d Sess. (1982); H.R. 5872, 97th Cong., 2d Sess. (1982); see 128 ConG. REC. S2306 (daily ed. Mar. 17, 1982) (noting introduction of S. 2222 by Sen. Simpson); Id. at H951 (noting introduction of H.R. 5872 by Rep. Mazzoli); see also House Committee Report, supra note 1, at 54.

15. On February 17, 1983, Congressman Romano L. Mazzoli (D.-Ky) introduced H.R. 1510, the Immigration Reform and Control Act of 1983. This was essentially the same bill passed by the House Judiciary Committee in the 97th Congress. See House Committee Report, supra note 1 , at 55.

16. On July 25,1985 , the Chairman of the Judiciary Committee, Peter W. Rodino, Jr. (D.-NJ) and the Chairman of the Subcommittee on Immigration, Refugees and International Law, Congressman Mazzoli, jointly introduced H.R. 3080, the Immi- 
gress in both the House and Senate.

A commitment to address the immigration issue became a priority in the newly inaugurated Reagan Administration. President Reagan established a cabinet-level task force to review the Select Commission's report and refine its recommendations. Then, under the leadership of Attorney General William French Smith, the Administration took the initiative by introducing an omnibus reform proposal. ${ }^{17}$ It included among its major provisions employee sanctions, a temporary foreign worker program for up to 50,000 Mexican nationals, a legalization program, a seven-part program to deal with mass migrations, and an increase in the legal immigration ceilings for Canada and Mexico. As early as July 30,1981, the President outlined the essential contours of a workable immigration policy:
We must ensure adequate legal authority to establish control over immigra- tion; to enable us, when sudden influxes of foreigners occur, to decide to whom we grant the status of refugee or asylee; to improve our border con- trol; to expedite, consistent with fair procedures and our Constitution, re- turn of those coming here illegally; to strengthen enforcement of our fair labor standards and law; and to penalize those who would knowingly en- courage violations of our laws. The steps we take to further these objectives, however, must also be consistent with our values of individual privacy and freedom. ${ }^{18}$

Thus, both the Select Commission report as well as the Reagan Administration proposal, while differing somewhat in their specific content, sought to address the challenges posed by immigration in a comprehensive fashion. The die had been cast in a fashion that was to have a lasting effect on the ultimate shape and contours of the subsequent congressional response.

\section{ImMigRation Reform IN THE 97Th CONGRESS}

In the 97th Congress, Senator Simpson and Congressman Mazzoli introduced the Immigration Reform and Control Act of 1981 on May $19,1982 . .^{19}$ While at first glance, a Senator from Wyoming and a Congressman from Kentucky might not seem to be the most likely

gration Control and Legalization Amendments Act of 1985. Senator Alan K. Simpson (D.-Wyo), in the other body, introduced S. 1200, 99th Cong., 1st Sess., 131 CoNG. ReC. S7038 (daily ed. May 23, 1985); see also House Committee Report, supra note 1, at 5556.

17. S. 1765, 97th Cong., 1st Sess. (1981); H.R. 4832, 97th Cong., 1st Sess. (1981). See generally Eig \& Vialet, Immigration Reform: History and Current Statutes, 1 GEO. IMMIG. L.J., Fall 1985, at 30.

18. Administration's Proposal on Immigration and Refugee Policy: Joint Hearing before the Subcomm. on Immigration, Refugees, and International Law of the Comm. on the Judiciary, House of Representatives, and the Subcomm. on Immigration and Refugee Policy of the Senate Comm. on the Judiciary, United States Senate, 97th Cong., 1st Sess. 7 (1981) (restatement of President Reagan by Hon. William French Smith, Attorney General of the United States) [hereinafter Administration's Proposal].

19. See sources cited supra note 14; see also House Committee Report, supra note 1 , at 54 . 
sources of an omnibus immigration reform package, as the Chairmen of the Immigration Subcommittees of their respective chambers, they addressed the challenge.

The original bills contained provisions which formed the legislative framework for reform - employer sanctions, a streamlining of the adjudicatory system, changes in the H-2 temporary agricultural worker status, and a two-track legalization program under which those who entered the United States illegally before a 1977 cut-off date would qualify for permanent resident status and those who entered prior to January 1,1980 , would be classified as temporary residents for three years. In addition, the two bills included a cap on legal immigration with respect to the unlimited "immediate relative category" and the "fifth preference" involving brothers and sisters of United States citizens. ${ }^{20}$

The Senate went right to work on its bill and passed the legislation on August 17, 1982, by a vote of 80 to $19 .{ }^{21}$ In the House, the Subcommittee on Immigration marked up its bill on May 19, 1982. ${ }^{22}$ However, having been "burned" before, the Chairman of the full Committee on the Judiciary, Peter Rodino, decided to delay consideration until the bill had passed the Senate. In Committee the bill remained largely intact except for the provisions affecting legal immigration which were deleted at Chairman Rodino's insistence. On September 22, 1982, the House Judiciary Committee reported a bill. ${ }^{2 s}$

Unfortunately, delayed consideration of the bill brought the fate of the legislation into conflict with the legislative clock. Despite a post-election "lame duck" session, the bill was allowed to come to the House floor facing over 100 amendments. That was the death knell for immigration reform in the 97th Congress.

20. Compare S. 2222, 97th Cong., 2d Sess. (1982) with H.R. 5872, 97th Cong., 2d Sess. (1982); see 128 CONG. REC. S2306 (daily ed. Mar. 17, 1982) (noting introduction of S. 2222 by Sen. Simpson); 128 Cong. Rec. H951 (daily ed. Mar. 17, 1982), (noting introduction of H.R. 5872 by Rep. Mazzoli); see also IMMIGRATION REFORM and Control Act of 1986 (Pub. Law. No. 99-603): A Summary and Explanation, 99th Cong., 2d Sess. 6.7 (1986).

21. 128 CONG. REC. S10,609 (daily ed. Aug. 17, 1982); see also IMMIGRATION Reform and Control ACT OF 1986 (P.L. 99-603): A Summary aNd EXPLANATION, 99th Cong., 2d Sess. 6-7 (1986). 1982).

22. H.R. 5872, 97th Cong., 2d Sess., 128 Cong. Rec. D635 (daily ed. May 19,

23. H.R. 6514, 97th Cong., 2d Sess., 128 Cong. Rec. D1236 (daily ed. Sept. 22, 1982); H.R. REP. No. 890, 97th Cong., 2d Sess. (1982). 
Neither Congressman Mazzoli nor Senator Simpson were deterred by this setback. Immediately, they picked up where they had left off. The Immigration Subcommittee once again held extensive hearings on the issue, making great efforts to ensure that the detractors of the legislation in the prior Congress had an opportunity to fully air themselves.

Senator Simpson introduced S. $529^{24}$ and the bill once again passed the full Senate by a vote of 76 to $18 .^{25}$ In the House, the road proved rocky once again. As in the previous year, action was delayed by the full Committee until the Senate had completed its task. While the basic framework of the bill was retained, an agricultural transition program (to smooth the transition from a largely undocumented labor force to the $\mathrm{H}-2$ program over a three-year period) was added to the bill at Subcommittee. ${ }^{26}$ At the House Judiciary Committee level, a significant change was made to the legalization program: the cut-off date was moved from January 1, 1981, as adopted in Subcommittee, to January 1, 1982.27

Following consideration by the House Judiciary Committee, the legislation was sequentially referred to the Education and Labor Committee (concerned with agricultural labor issues and the question of discrimination), the Agriculture Committee (concerned with agricultural labor issues), and the Energy and Commerce Committee (concerned with social service and health care questions related to legalization). ${ }^{28}$

In October of 1983, House Speaker Tip O'Neill announced that he would not allow the immigration reform bill to be considered on the House floor; this compounded the obstacles facing immigration reform. While divisions within the Democratic Party and presidential politics were the underlying motivation for this decision, the editorial response across the nation was so overwhelming that it was soon apparent that the Speaker had misjudged the situation and would have to reverse his decision.

After a delay of six months, the immigration reform bill temporarily escaped this latest threat to its survival and the next stop was at

24. See 129 Cong. Rec. S. 1343 (daily ed. Feb. 17, 1983) (statement of Sen. Simpson) ("I am reintroducing the same bill today that the Senate passed last August."). For further reading on legislative activity in the 98th Congress, see Smith, Immigration Law Reform: Proposals in the 98th Congress, 21 SAN DIEGo L. REv. 7 (1983).

25. See 129 Cong. Rec. S6969-70 (daily ed. May 18, 1983).

26. Eig \& Vialet, supra note 17 , at $31-33$. 1510).

27. H.R. REP. No. 115, 98th Cong., 1st Sess. pt. 1 (1983) (accompanying H.R.

28. For a general discussion of this legislative process, see Eig \& Vialet, supra note 17 , at $31-32$. 
the House Rules Committee. In retrospect, the Committee deserves much praise for crafting a rule that allowed a fair consideration of the major controversial issues while avoiding the legislative anarchy which had doomed the bill in the previous Congress - between June 11 and June 20,1984, the House considered and debated some sixtynine different amendments. ${ }^{29}$

Unfortunately, the lengthy delay between floor action and the House-Senate conference coupled with the makeup of the House conferees (which included a large number of opponents of the legislation) gave those who sought to kill the bill the swing votes that led to a deadlock. The conference unraveled. The issue on which everything came apart involved a question that received little attention during the House debate. An amendment offered by Congressman Barney Frank on the House floor would have established an enforcement structure analogous to the National Labor Relations Board (NLRB) for cases involving hiring discrimination. The most contentious element of the provision would have made it illegal for a private employer to distinguish between citizens and noncitizens in their hiring practices. Last-minute efforts were made to construct a compromise including a $\$ 1$ billion cap on reimbursement to the states for welfare reimbursement in order to increase support among some Republicans for the Frank amendment. It came to naught, as the clock once again ran out on immigration reform. ${ }^{30}$

\section{ImMigRation Reform IN THE 99Th CONGReSS}

On May 23, 1985, Senator Simpson introduced S. 1200. Hearings were held in mid-June and it was reported by the full Senate Judiciary Committee on August 28, 1985. ${ }^{31}$ It passed the Senate by a vote of 69 to 30 on September 19, 1985. ${ }^{32}$ H.R. 3080 was introduced by Congressmen Rodino and Mazzoli on July 25, $1985 .{ }^{33}$ Hearings were held in September and October 1985, and the bill was marked up in the House Subcommittee on Immigration in November $1985 .^{34}$ It

29. See House Committee Report, supra note 1, at 55; see also Eig \& Vialet, supra note 17, at 31-34.

30. Eig \& Vialet, supra note 17 , at 34.

31. See S. REP. No. 132, 99th Cong., ist Sess. (1985). 1985).

32. S. 1200 , 99th Cong., 1st Sess., 131 CoNG. REc. S11750 (daily ed. Sept. 19,

33. H.R. 3080, 99th Cong., Ist Sess., 131 Cong. REc. H6353 (daily ed. July 25, 1985).

34. Immigration Control and Legalization Amendments: Hearings Before the House Subcomm. on Immigration, Refugees, and International Law, 99th Cong., 1st Sess. (1985). 
was not until June 25, 1986, seven months later, that markup of the bill occurred in the full House Judiciary Committee. Once again, we were in the final days of this session of Congress attempting to work out the details of an important reform bill. The full Committee markup of the bill occurred on June 25, 1986, and it was reported from the Committee by a vote of 25 to $10{ }^{35}$ On October 9,1986 , the House passed the bill ${ }^{38}$ and the House-Senate conference was accepted by the House on October 14, 1986, ${ }^{37}$ and by the Senate on October $17,1986 .^{38}$ The President signed the bill on November 6, 1986.38

It might be queried as to how - for the third time - we found ourselves facing adjournment with immigration reform legislation hanging in the balance. The answer lies in the fact that the Chairman of the House Judiciary Committee and other members on the Democratic side of the aisle sought to reach an accord on the question of the admission of foreign agricultural labor, while at the same time, precluding me from introducing a guest worker amendment similar to both the so-called Panetta-Morrison amendment adopted in the previous Congress and the Wilson amendment adopted in the current Senate bill, S. $1200 . .^{40}$ The obvious concern was that my amendment, if brought to the floor, probably would pass. The effect was a series of negotiations among only the Democratic members which delayed action in the Committee as well as action on the House floor.

When the bill finally was brought to the House Rules Committee on September 23, 1986, I sought a rule that would allow a vote on my amendment as a substitute for the provisions contained in the House Judiciary Committee bill. ${ }^{11}$ As written, the Judiciary Committee bill would have granted temporary resident status to farm workers who had worked sixty days in American agriculture between May 1985 and May 1986. These workers would not have been required to remain in agriculture once they obtained permanent resident status and would have been eligible for most welfare benefits.

The rule reported by the Rules Committee ${ }^{42}$ precluded any debate on this controversial area of the bill. Furthermore, it included a pro-

35. See House Committee Report, supra note 1 , at 46.

36. See 132 Cong. Rec. H9698-H9708 (daily ed. Oct. 9, 1986).

37. See id. at $\mathrm{H} 9940$ (daily ed. Oct. 14, 1986).

38. See id. at S16879 (daily ed. Oct. 17, 1986).

39. Immigration Reform and Control Act of 1986, Pub. L. No. 99-603, 100 Stat. 3359 (1987) [hereinafter IRCA].

40. See infra text accompanying notes 102-08.

41. 132 CoNG. REC. H8523-27 (daily ed. Sept. 26, 1986) (statement by Rep. Daniel E. Lungren); see Rules Comm. Hearing on the Immigration Reform and Control Act of 1986, 99th Cong., 2d Sess. (1986).

42. See H.R. Res. 559, 99th Cong., 2d Sess. (1986); H.R. REP. No. 875, 99th Cong. 2d Sess. (1986). 
vision which would have barred the Immigration and Naturalization Service (INS) from deporting Salvadorans and Nicaraguans in a fashion envisioned by the even more controversial Moakley-DeConcini Extended Voluntary Departure (EVD) bill..$^{43}$

This was simply unacceptable to the vast majority of those of us on the Republican side of the aisle. Accordingly, on September 26, 1986 , we sought through a procedural motion a vote on the previous question which would have allowed the rule to be amended. On this point, we were defeated by a vote of 196 to 189.44 Voting the rule down was the only available alternative; we did this by a vote of 202 to $180 . .^{45}$

At the time, it was believed by many that such action would be the death knell to immigration reform in the 99th Congress. In fact, the Washington Post carried an interesting editorial on September 30, 1986, which queried, "And A Failure On Immigration?" It answered its own rhetorical question by explaining, "The bill presented to the House for a rule last week, though, was not a balanced compromise, and the rule that was proposed for the debate would have locked in a series of controversial amendments . . ."46

The Post editorial then responded to the "finger-pointing" concerning responsibility for the death of the legislation:

Some in the House leadership are now claiming that the Republicans killed the immigration bill by refusing to accept a controversial package without change. That's not fair, for many who voted against the rule would have supported a bill after debate and a series of votes. ${ }^{17}$

While our decision to defeat the rule was obviously a politically risky proposition, as well as a danger to the bill substantively, the House would have defeated the legislation in its existing form anyway. In other words, it was better to use the rule's defeat as a means of confronting the problems in the bill while there was still time to make changes that would enhance its chances for passage.

Despite suggestions to the contrary, at no time did those of us who made the decision to defeat the rule ever feel that this would end any chance for immigration reform in the 99th Congress. On October 1, 1986, we attempted a tactic aimed at using a little-known provision of the House rules. Under rule XI, clause 4(c), any member of the

43. See infra note 55 and accompanying text.

44. See 132 CONG. REC. H8523-26 (daily ed. Sept. 26, 1986). (Statement of Rep. Trent Lott (R.-Miss.)).

45. Id. at $\mathrm{H} 8525$.

46. Washington Post, Sept. 30, 1986, at A14, col. 1.

47. Id. 
Rules Committee can call up any resolution that has been reported by the Rules Committee and which is pending action. ${ }^{48}$ This seemingly obscure rule contained an enormous strength - it provided an absolute opportunity for the minority party to reintroduce the issue of immigration reform to the House floor for an open debate. ${ }^{49}$

Although this effort to "bootstrap" a new immigration rule onto the rule for the Department of Justice Authorization bill went down to defeat by a vote of 235 to $177,{ }^{50}$ it had a telling effect on the course of events to follow. We made it absolutely clear that the Republicans were not only serious about immigration reform but also committed to forcing the House Democratic leadership to allow us to participate in the legislative process. For the first time I was invited to participate in a new series of negotiations concerning the agricultural labor issue and other controversial provisions which had led to the defeat of the rule. Congressmen Mazzoli, Fish, Rodino, Schumer, Berman, Panetta, Bryant, Frank, Morrison, and I met in Chairman Rodino's office on October 2, 3, 6, and finally reached agreement on October 7. In order to ensure that all this effort would not be in vain, we essentially "pre-cleared" the agricultural labor provisions with Senator Simpson and other members of the Senate.

On the night of October 7, the House Rules Committee produced a rule ${ }^{51}$ which was consistent with the understanding which had been reached on the agricultural labor issue and allowed a vote on the question of EVD for Salvadorans and Nicaraguans.

The bill which reached the House floor included a provision incorporated by the Rules Committee which would have provided a sunset of employer sanctions after a period of six and one-half years. ${ }^{62}$ This was in contrast to the Kennedy amendment contained in the Senate bill which would have required a showing of discrimination before the sanctions would have been subject to a sunset.

48. See Rules of the House of Representatives, Rule XI, cl. 4(c).

49. Congressman Trent Lott, a member of the Rules Committee and the Minority Whip, explained his action to exercise rule XI, clause $4(\mathrm{c})$ :

Our intention here by calling up this rule is to have the full hour for debate, in which we will explain exactly what we are trying to do on the immigration reform rule, and after that 1 hour of debate we would urge our colleagues to defeat the previous question, defeat the previous question, at which point a rule would be offered allowing for immigration reform to be considered, a fair rule, that would make in order the bill that was reported by the Committee on the Judiciary, the rule that was reported by the Committee on Rules, but with some very crucial changes in that rule, that would be a bipartisan change in the rule, so that we can get this issue up.

132 Cong. ReC. H8796 (daily ed. Oct. 1, 1986) (statement of Rep. Trent Lott (R.Miss.)).

50. Id. at $\mathrm{H} 8804$. 1986).

51. See House Rule H.R. Res. 580, 132 Cong. Rec. D1284 (daily ed. Oct. 8, 52. Id. 
As in the prior Congress, the discrimination issue had led to a significant debate over the so-called Frank amendment. The most controversial aspect of the amendment created a new cause of action for alienage discrimination, that is, discrimination on the basis of noncitizenship. It was my feeling that unless this issue was addressed on the House floor, it could potentially lead to another stalemate. Many members believed that there may be a host of reasons why an employer might prefer to hire a citizen over a noncitizen which are not connected to discrimination. Accordingly, the House adopted my amendment to provide that if two equally qualified individuals, one a citizen, the other a noncitizen, apply for the same job, a mere preference for the citizen would not ipso facto lead to a finding of discrimination. ${ }^{53}$ While the administrative apparatus set up to enforce the Frank amendment was still troublesome to some, it was my feeling that my "citizenship on equal terms amendment" would mitigate the major opposition to the provision and increase the likelihood that we would adopt legislation.

Another significant area of debate on the House floor concerned the McCollum amendment to eliminate the legalization provisions contained in the bill. Congressman Bill McCollum of Florida, a supporter of immigration reform, had introduced an identical amendment in the prior Congress which was defeated by a vote of 233 to 195. The debate this time around was once again emotionally charged. To the surprise of many, the legalization provisions of the bill were sustained by a margin of only seven votes - 199 to $192 .{ }^{54}$ This vote clearly indicated that a considerable amount of support for legalization had been lost within a two-year period. To some extent this can be attributed to "compassion fatigue" and concern over the potential magnitude of the program. In addition, the inclusion of the modified Schumer agricultural program may have mitigated, to some extent, support for the general legalization program.

Another area of the bill which generated much debate involved the issue of EVD for Salvadorans or Nicaraguans. With language taken from the Moakley-DeConcini bill, ${ }^{\mathrm{s}}$ this section would have barred the deportation of individuals from both of these groups until after the completion of an eighteen-month study conducted by the General Accounting Office (GAO) concerning conditions in Central

53. See 132 Cong. Rec. H9767-69 (daily ed. Oct. 9, 1986).

54. See id. at D1291 (Roll Call No. 455).

55. H.R. 822, 99th Cong., Ist Sess. (1985); see also H.R. REP. No. 755, 99th Cong., $2 d$ Sess. pt. 1 (1986). 
America. The practical effect of the section would have been to grant de facto permanent resident status to all within these groups, irrespective of their reasons for coming to or remaining in the United States. The significance of this legislation in the context of the immigration bill, however, is that it was even more controversial than the question of immigration reform itself. Yet on an extremely close vote of 199 to 197, an amendment offered by Congressman Hamilton Fish to strike the provision from the bill failed. ${ }^{B B}$

The remaining hurdle of final passage was overcome with seeming ease. This was significant because in the last Congress, the legislation was adopted by only a five-vote margin (216 to 211). ${ }^{87}$ This time the final margin of victory was considerably larger with a vote of 230 to 166 in favor of the bill. ${ }^{88}$ This change of sentiment can be explained by a number of factors. First, the learning curve on this issue had generated a consensus that reform was necessary for our country. Secondly, while the bill was not an ideal response from anyone's perspective, the fact that it was now viewed as a true compromise increased support from some who had not earlier supported immigration reform.

While the agricultural labor provisions were clearly a stumbling block in getting a bill to conference, it was somewhat of a luxury to have already reconciled the major differences with respect to the shape and contours of the program.

With little time for delay, the bill went to Conference by October $10,1986,,^{59}$ where the last efforts to work out the differences between the House and Senate versions of the bill were made.

One issue of major concern at the Conference was the different treatment of the respective sunset provisions in the House and Senate bills. Under the House version, the sanctions would have sunset automatically after six and one-half years from the date of enactment. Under the Senate provisions, discrimination attributable to sanctions would have to be reported by the GAO and acted on by the Congress before the sunset provisions would be terminated. ${ }^{60}$

Employer sanctions are obviously the heart of the enforcement thrust of the legislation. Hence, an automatic sunset provision was not acceptable to most of the Republican members as well as to the Senate Conferees. The approach adopted by the Senate had been crafted by Senator Kennedy and was directly tied to the question of

56. See H.R. 822, 99th Cong., 1st Sess. (1985); 132 CoNG. REC. D1291-2 (daily ed. Oct. 9, 1986) (Roll Call No. 456).

57. See 130 Cong. Rec. H6149 (daily ed. June 20, 1984) (Roll Call No. 251).

58. 132 Cong. Rec. DI291 (daily ed. Oct. 9, 1986) (Roll Call No. 457).

59. See id. at D1300 (daily ed. Oct. 10, 1986). 121 (1986).

60. S. 1200, 99th Cong., 2d Sess. (1986); S. REP. No. 132, 99th Cong., 2d Sess. § 
discrimination. ${ }^{61}$ The problem in the House bill was that it could give rise to a sunset regardless of whether discrimination was found to exist. Under such a formulation, it would have been possible to have a significant legislation program without any assurance that the major enforcement provision of the bill would endure. The symmetry created by the dual tracks of legislation and enforcement would be destroyed. Aside from the public policy questions raised by the amendment, it was most unlikely that such an approach could have passed the Senate. In the end, the Senate provisions were adopted. ${ }^{62}$

Another issue related to employer sanctions concerned employer verification of the eligibility of new employees to work in the United States. The House bill provided that every employer be required to verify any two out of a number of documents ${ }^{63}$ and attest in writing that he or she had seen the documentation. Following this process would raise a presumption of compliance in hiring on the employer's behalf should he or she ever be charged with a violation of the sanctions provision. Rather than mandate such a paperwork burden, the Senate version left it voluntary; however, in the absence of paperwork, it created a presumption against the employer to the effect that he or she would be considered to have knowingly hired any employees who turned out to be illegal. In the end, the Senate version was seen to be unworkable and was rejected by the Conference.

The language of the Senate bill directing the President to monitor and evaluate the verification system was accepted. If the President finds that the system is not secure, provision is made for the adoption of a more secure system of employment authorization. ${ }^{64}$ It should also be noted that the bill includes enhanced criminal penalties for the misuse of these immigration-related documents.

As in the previous House-Senate conference, the question of reimbursement to the states for social service costs incurred by those to be legalized received a great deal of attention. The provisions in the House bill provided "such sums as are necessary," while the Senate bill contained a capped entitlement for grants to states for $\$ 300$ million each year for the two years following the end of the legalization application period and $\$ 600$ million each year for four years. The focus of the debate, however, centered around comments made by

61. Id.

62. See supra text accompanying notes 37-39.

63. Compare H.R. 3810, 99th Cong., 2d Sess. (1986); H.R. REP. No. 682, 99th Cong., 2d Sess. (1986) with S. 1200, 99th Cong., 2d Sess. \$ 101 (1986); S. REP. No. 132, 99th Cong., 2d Sess. \& 121 (1986).

64. IRCA § $101(\mathrm{a}), 100$ Stat. at 3363 (amending/adding INA § 274(d)(1)(A)). 
the President to a number of us during an Oval Office meeting in the White House in early 1986. At that time, the President had indicated that he could accept a reimbursement program which included a cap of $\$ 1$ billion per year, for a period of four years.

Although data provided by the Congressional Budget Office (CBO) indicated that this would be more than sufficient to cover anticipated expenses, ${ }^{65}$ representatives from state and local governments wanted a guaranteed $100 \%$ reimbursement. While it was probable that such an approach would have resulted in a veto, there were some who had difficulty comprehending that, in the absence of passage of the bill, state and local jurisdictions would receive nothing. Throughout the entire legislative process, many of them had to be reminded of a simple mathematical calculation; that is, $100 \%$ of nothing equals nothing. The universe of those to be legalized was limited to those already in this country. And, since those illegal aliens were already using public services to some degree, it was hard to imagine how the plight of local jurisdictions would not be greatly alleviated with the one billion dollar annual commitment. Moreover, a blank federal check for programs largely structured on the state and local level is not a formula for fiscal responsibility through vigorous oversight. The cap was ultimately adopted in the Conference.

Another difference between the House and Senate bills was the legalization date. Under the House bill, temporary status would have been provided to those aliens who entered this country or fell into illegal status prior to January 1,1982 , and who have continuously resided in the United States since then. The alien beneficiary would then be eligible to adjust to permanent resident status after one year, upon a demonstration of basic citizenship skills. Under the Senate bill, temporary status would have been provided those aliens in the United States in an undocumented status prior to January 1, 1980, only after a commission established under the bill issued its findings that effective enforcement was instituted, or three years from the date of enactment, if later.

The Conference did not have as much difficulty with this issue as was expected. The passage of time itself had brought the 1982 date, which then amounted to a five-year period of continuous residency, to the point where a majority of Conferees recognized that sufficient equities would exist in this class of people to justify such an extraordinary remedy. Consequently, the House position was adopted. ${ }^{88}$

The final issue which generated much controversy was reconcilia-

65. See the information provided by CBO in H.R. REP. No. 682, 99th Cong., $2 \mathrm{~d}$ Sess. 127-35 (1986).

66. IRCA § 201 (a), 100 Stat. at 3394 (amending/adding INA § 245A(a)(2). 
tion of the differences surrounding EVD. As a vigorous opponent of the concept, Senator Simpson was expected to resist the effort to deal with this issue in the context of the immigration bill. Certainly the Reagan Administration was expected to veto any bill containing the Moakley-DeConcini approach. While the policy arguments surrounding EVD are beyond the scope of this Article, many questioned loading additional "baggage" onto a bill which already approached excessive magnanimity. However, the tragic Salvadoran earthquake generated sufficient sympathy to provide a gesture of concern for those in the United States who might be affected. The Conference Committee decided to include language in the statement of managers suggesting that the Attorney General consider the effects of this tragedy with respect to Salvadoran deportation cases. The EVD language was otherwise dropped from the bill.

\section{Major Provisions of the Immigration Reform and Control ACT}

The law that emerged from the 99th Congress contains common elements of the legislation from the past several congresses. These elements have been integral to the immigration reform debate and have been included in immigration legislation since the Select Commission issued its 1981 report. The historical genesis of these provisions dates back to the first legislative efforts in the 1950's.

\section{Employer Sanctions}

The centerpiece of this comprehensive immigration reform bill is sanctions against employers who knowingly hire, refer, or recruit undocumented aliens for jobs. Previous law imposed no sanctions on employers who hire illegal aliens. ${ }^{67}$

As a nation we could no longer ignore the collective wisdom of four administrations and the Select Commission which told us that any comprehensive reform effort must embody employer sanctions as the key element of enforcement. If we are going to "demagnetize" the attraction of employment in the United States, we must have sanctions for employers who knowingly hire those who enter without benefit of papers. Without effective employer sanctions, the United States will be unable to regain control of its borders. ${ }^{68}$

67. See Immigration and Nationality Act of 1952, 66 Stat. 163 (codified as amended at 8 U.S.C. $\$ \S 1101-1503$ (1982)).

68. See Select Comm'n Final Report, supra note 12, at 61; see also Immigration Reform \& Control Act of 1983: Hearings on H.R. 1510 Before the House Sub- 
Nevertheless, the concept remained controversial. During congressional hearings on immigration reform, Congress heard several arguments against the implementation of employer sanctions. ${ }^{6 \theta}$

Some argued that it would be preferable to deal with the immigration problem through United States foreign assistance to countries from which people emigrate. ${ }^{70}$ Admittedly, poor conditions in lessdeveloped countries usually give rise to the incentive to leave. However, as long as the relative wage rates are higher in the United States than in the sending countries, there will be strong incentives for undocumented aliens to make the trek here.

To be sure, some foreign assistance measures, such as the Caribbean Basin Initiative, are necessary. But economic development is a long-term process. Given the problems posed by collectivist economic policies of many less-developed countries, it is simply not possible to eliminate the disparities overnight. In any event, Congress does not have the luxury of avoiding the present onslaught of illegal immigration in hopes that problems within the sending countries will be addressed sometime in the distant future.

Critics have charged that the mixed experience in other countries and in eleven states demonstrates that employer sanctions will not work. It is true that one GAO report did indicate that sanctions were not uniformly successful in the nineteen countries that were studied. But more to the point, the study referred to the significant reasons behind the findings - primarily insufficient penalties and a general lack of enforcement. ${ }^{71}$ In Germany, for example, the burden for implementing the law has fallen almost exclusively on local police. Also, because lenient judges have imposed minimal fines, sanctions have had little deterrent effect. The situation was much the same in France.

In fact, the report to Congress stated nothing more controversial than when laws are not enforced, they do not work. A subsequent GAO report suggested that there has been a change in attitude about the need for enforcement; preliminary indications are positive. For instance, both Germany and France have strengthened their em-

comm. on Immigration, Refugees, and International Law, 98th Cong., 1st Sess. 242-73 (1983) (Testimony of Alan Nelson, Commissioner of the INS) [hereinafter House Hearings, 98th Cong.].

69. See Immigration Control and Legalization Amendments: Hearings Before the House Subcomm. on Immigration, Refugees, and International Law, 99th Cong., 1st Sess. (1985).

70. See House Hearings, 98th Cong., supra note 68, at 902-26 (Testimony of John Heurta, Associate Counsel of Mexican American Legal Defense and Education Fund).

71. See General Accounting Office, Illegal Aliens: Information on Selected Countries' Employment Prohibition Laws, No. GAO-GGD-86-17BR 1-3 (1985). 
ployer sanctions. ${ }^{72}$ In fact, the report indicates that most countries reported that employer sanctions have helped to deter illegal alien employment. ${ }^{73}$

Another criticism of employer sanctions is that they will encourage discrimination against "foreign-looking" individuals. Such a charge is ironic since those of us who supported employer sanctions did so with the express intent to prevent, rather than promote discrimination. The illegal status of undocumented workers has been one of the primary causes of exploitation and discrimination in the workplace. Moreover, this sub rosa labor pool displaces American minority workers from available job opportunities. ${ }^{74}$

Nonetheless, the sponsors of the legislation recognized the concerns about unintended discrimination which could arise from a poorly drafted or implemented law. Therefore, in crafting employersanctions provisions, Congress tried to build in safeguards to ensure uniform application. The verification requirements of the bill require the employer to verify the employment status of everyone hired regardless of appearance or speech pattern. ${ }^{75}$ The Conference agreement embodied provisions of the House bill which will establish an enforcement vehicle analogous to the NLRB with a special counsel to investigate and prosecute allegations of discrimination.

Some have alleged that employer sanctions would impose an unfair burden on employers. This is simply not true. The legislation merely requires the inspection of any two out of a number of possible documents, such as a passport, Social Security card, alien documentation or driver's license, to ensure the employee's identity and eligibility to work in the United States. ${ }^{76}$ This would, in most cases, parallel the normal hiring process. Both employer and employee would then sign a single form as evidence of compliance with the law. ${ }^{77}$ Our country has a compelling national interest in regulating immigration - one that warrants cooperation from the private sector.

72. Id. at 8-9, 10-11.

73. Id.

74. See "The Knowing Employment of Illegal Immigrants": Hearing before the Subcommittee on Immigration and Refugee Policy, Senate Judiciary Committee, 97th Cong., 1st Sess. (1981).

75. IRCA § 101(a), 100 Stat. at 3360 (amending/adding INA § 274A(a)(1)(B).

76. Id. $\S 101(\mathrm{a}), 100$ Stat. at 3361-62 (amending/adding INA § 274A(b)(1)(B), (C) and (D).

(2)).

77. Id. § $101(\mathrm{a}), 100$ Stat. at 3361-62 (amending/adding INA § 274A(b)(1), 


\section{Legalization}

Another provision of this legislation central to the historical discussion of immigration reform legislation involves legalizing those who reside within our communities without benefit of papers. ${ }^{78}$ The question of legalization arose only because Congress had failed in the past to muster the courage to reform our immigration laws. The primary reason that we currently have a large undocumented population in our midst is that we have had neither a sufficient body of law nor sufficient resources underlying our enforcement policy. We simply were not able to apprehend these people when they entered our country illegally.

The question of legalization also bears on the enforcement thrust of immigration reform legislation. The attempt to regain control over our borders must of necessity involve the most effective utilization of scarce resources. This end is best served by an emphasis on eliminating the future flow of illegal immigration along the border. In addition, legalization has been considered an essential element of immigration reform to deal with the humanitarian concern of those individuals - although illegal - who have established roots in the United States.

A failure to provide a substantial legalization program would ignore the equities of those people who have lived in the United States for a number of years, perpetuate the existence of a large underclass of illegal aliens, and continue to subject citizens and lawful permanent resident aliens, as well as undocumented aliens, to enormous social costs.

The 1981 Select Commission's unanimous vote in favor of legalization underscored the absence of a viable alternative to conferring legal status on many undocumented aliens. ${ }^{79}$ The United States simply lacks the machinery to deport millions of people. An attempt at mass deportation, moreover, would subject members of minority groups to probable discriminatory treatment and involve the United States in foreign policy difficulties with major sending countries. For these reasons, a legalization program was not only preferable, it was essential.

The bill adopted by the Congress grants one-year temporary status for undocumented aliens who have been physically present and who have continuously resided in the United States, except for brief casual innocent absences, since the date of enactment and also have resided in the United States since before January $1,1982 .{ }^{80}$ Persons

78. Id. § 201(a), 100 Stat. at 3394 (amending/adding INA § 245A).

79. See SELECT COMM'N FINAL RePORT, supra note 12, at 72-75. (1986)).

80. IRCA \& 201(a), 100 Stat. at 3394-95 (amending/adding INA § 245A(a) 
receiving temporary status will be able to adjust to permanent resident status after eighteen months from the date that temporary residence is granted. ${ }^{\mathbf{8 1}}$ In order to qualify the alien must satisfy minimum English requirements and a minimum understanding of American government and history. The Attorney General can waive these required citizenship skills in cases involving aliens sixty-five years or older. ${ }^{82}$

\section{The Foreign Worker Program for Agriculture}

Since the 97th Congress, immigration legislation has included a streamlined H-2 agricultural worker program. Additionally, the House, during the 98th Congress, and the Senate, during the 99th Congress, adopted agricultural provisions to address the concerns of those who grow perishable commodities. ${ }^{83}$ Although a small portion of the total number of undocumented aliens work in agriculture, the agricultural industry itself is heavily dependent on an illegal workforce. The undocumented population in agriculture is estimated to be only fifteen percent of the total undocumented population. ${ }^{\mathbf{8 4}}$

As former INS Commissioner Leonel Castillo eloquently characterized the situation sometime ago, "the U.S. is experiencing the world's largest temporary worker program, larger than the guestworker programs of France, Holland and Germany. Only ours is unregulated ... resulting in the Immigration Service having to arrest over a million persons annually ... whose crime is that they want to work in this country." was to control the number of foreign workers coming into this country and still meet the needs of agriculture - especially for those who find the current $\mathrm{H}-2$ program not adequate to serve their agricultural needs.

Congress has sought through this legislation to regularize the flow of undocumented aliens into a legal framework that will afford legal protection of foreign workers as well as protection of domestic workers from displacement and satisfaction of the legitimate needs of American agricultural producers.

The United States produces more than $\$ 130$ billion of agricultural

81. Id. § 201(a), 100 Stat. at 3395-97 (amending/adding INA § $245 \mathrm{~A}(\mathrm{~b})$ ).

82. Id. \$ 201(a), 100 Stat. at 3396 (amending/adding INA § 245A(b)(D)(ii)).

83. See H.R. 1510, 98th Cong., 1st Sess. (1983); S. 1200, 99th Cong. 1st Sess. (1985).

84. Administration's Proposal, supra note 18, at 7 (Testimony of Attorney General William French Smith).

85. 132 CoNG. Rec. H2578 (daily ed. May 9, 1986). 
products annually ${ }^{88}$ Nearly $\$ 14$ billion of that amount is accounted for by fruit, vegetables, and other labor-intensive commodities. More than 800,000 farmers employ hired workers and more than two million United States residents earn some or all of their income from farm work. ${ }^{87}$ Many millions more are employed in supply inputs to agricultural production or handling agricultural products. All of these people, indeed the entire nation, have a stake in an adequate agricultural workforce. ${ }^{88}$

The jobs of seasonal American farmworkers and of many farmers are dependent on an adequate supply of total seasonal agricultural labor (traditionally made up of foreign as well as domestic workers). Hundreds of millions of dollars of domestic payroll and farm income will be lost to foreign producers if adequate seasonal labor is not available to United States farmers. ${ }^{89}$

Agricultural employers in many areas of the United States cannot obtain adequate seasonal labor to meet their needs. Many United States workers appear to be unwilling or unable to accept short-term seasonal agricultural employment. Many of these jobs are in rural areas that would require United States workers to remain away from home as migratory workers for extended periods of time. The United States migratory agricultural workforce has declined dramatically in recent years, while the demand for labor in seasonally labor-intensive harvesting of fruit, vegetables and other commodities has increased. Since insufficient domestic labor is available for agriculture needs, many areas of the country depend on foreign workers to supplement domestic labor. ${ }^{80}$

\section{H-2 Agricultural Workers}

The Immigration and Nationality Act of 1952 authorized the temporary admission and employment of aliens in jobs for which there are not sufficient qualified and available United States workers, if the employment of the alien will not adversely affect United States workers similarly employed. ${ }^{91}$ In recent years, from 60,000 to 75,000 of these "H-2" workers have been admitted to the United States annually, about one-third of them for agricultural jobs. ${ }^{92}$

Admission of $\mathrm{H}-2$ workers is governed by regulations of the INS. ${ }^{93}$

86. Id. at $\mathrm{H} 2578$.

87. Id.

88. Id.

89. See House Hearings, 98th Cong., supra note 68, at 457-65 (Statement of Perry Ellsworth, National Council of Agricultural Employers).

E. Lungren)

90. 132 Cong. REC. H2578 (daily ed. May 9, 1986) (Statement of Rep. Daniel

91. INA § 101(a)(15)(H)(ii), 8 U.S.C. 1101(a)(15)(H)(ii).

92. 132 CONG. REC. H2578 (daily ed. May 9, 1986).

93. INA $\S 101(\mathrm{a})(15)(\mathrm{H})(\mathrm{ii}), 8$ U.S.C. $\$ 1101(\mathrm{a})(15)(\mathrm{H})(\mathrm{ii})$. 
The labor certification process is governed by regulations of the United States Department of Labor. ${ }^{94}$ Nonagricultural labor certifications, which make up about two-thirds of the total are subject only to local recruitment and local prevailing wages and benefits. ${ }^{95}$ Agricultural H-2 labor certifications are governed by a much more stringent set of requirements. ${ }^{96}$

The $\mathrm{H}-2$ program has sometimes made it possible to produce agricultural commodities requiring labor-intensive seasonal operations in areas where sufficient domestic labor was not available for these operations. ${ }^{97}$ This has expanded the economic base in these areas, creating more year-round and long-term seasonal agricultural jobs for United States farmers, farmworkers and workers in agri-business industries. On the heavy soils of south Florida, the raw sugar produced there provides thousands of year-round and seasonal jobs for United States workers and a $\$ 115$ million payroll in $1984 .^{98}$ The H-2 cane harvesters in south Florida earned a payroll of $\$ 35$ million in 1984, and averaged more than seven dollars per hour. ${ }^{99}$

The legislation passed by Congress codifies modifications intended to streamline the $\mathrm{H}-2$ program and make it more attractive to the agricultural community. ${ }^{100}$ The fact remains, however, that the 20,000 or so $\mathrm{H}-2$ agricultural workers in the program in recent years make up only a small part of our foreign agricultural labor force. The majority of this foreign labor force has been undocumented foreign migrant workers who have come here during certain times of the year to earn higher wages. It is difficult to estimate exactly how many of these foreign workers and their families actually have come to the United States at any one time. However, we do know that the number is several hundred thousand. ${ }^{101}$

94. 132 CONG. REC. H2578 (daily ed. May 9, 1986).

95. Id. See 20 C.F.R. pt. 655.

96. Lungren \& Holsclaw, An Analysis of the H-2 Program: The Admission of Temporary Foreign Agricultural Workers into the United States, YALE L. \& PoL'Y REv., Spring 1983, at 241.

97. Id.

98. 132 Cong. Rec. H2578-79 (daily ed. May 9, 1986) (Statement of Rep. Daniel E. Lungren).

99. Id. at $\mathrm{H} 2579$.

100. IRCA § 301 (a), 100 Stat. at 3411 (amending/adding INA § 216).

101. Temporary Workers: Hearing Before the Senate Subcommittee on Immigration and Refugee Policy, Senate Judiciary Committee, 97th Cong., 1st Sess. 16 (1981) (statement of A. James Barnes, General Council of the Department of Agriculture). 

Perishable Crops

Although the H-2 program works well for some growers, it has not worked for others, specifically in the perishable crop industry. In California, the $\mathrm{H}-2$ program has not been used to any degree. Those in agriculture in the western states find it more convenient to rely on an undocumented population that is, for all intents and purposes, beyond the protection of our labor laws. ${ }^{102}$ Those in western agriculture have argued that the perishable nature of their crops, as compared to sugar, made the regulatory maze of the $\mathrm{H}-2$ program (prior to the changes contained in IRCA) unresponsive to their needs. ${ }^{103}$

The needs of agriculture, as proven during the many years of congressional hearings and inquiry, impelled Congress to consider this issue on two separate tracks: an $\mathrm{H}-2$ provision and a perishable crop provision. I included a perishable crop provision in the bill I introduced in the 99th Congress - H.R. 1061. ${ }^{104}$ In the Senate the Wilson amendment was added to S. 1200 to accommodate the perishable crop industry. ${ }^{105}$ S. 1200 and the provision introduced in H.R. 1061 are similar to a provision adopted in the House bill, H.R. 529 in the 98th Congress, called the Panetta-Morrison amendment. ${ }^{108}$

The Wilson amendment, or perishable crop provision included in the Senate bill, S. 1200, created a program for the admission of temporary workers coming to the United States to perform seasonal agricultural services in perishable commodities, as defined by the Secretary of Agriculture by regulation. The provision allowed up to 350,000 such workers to be in the United States at any one time. The program would have sunset after three years. ${ }^{107}$

No labor certification was required ahead of time. Instead, a grower would be required to make a "good faith" effort to recruit domestic workers and would have to accept qualified domestic referrals and offer wages and working conditions that would not adversely affect domestic workers.

The Wilson proposal divided the nation into ten agricultural regions. Foreign workers with agricultural experience would be given preference over other foreign workers, and a trust fund, consisting of

102. See House Hearings, 98th Cong., supra note 68, at 535-36 (Testimony of Henry J. Voss, President of California Farm Bureau Federation).

103. Id.

104. H.R. 1061, 99th Cong., 1st Sess. (1985) (Introduced by Rep. Daniel E. Lungren); see also 131 CONG. REC. H401 (daily ed. Feb. 7, 1985) (noting introduction of bill).

105. For the Senate debate on the Wilson amendment, see 131 CoNG. REC. S11,319-27, $11330-44$ (daily ed. Sept. 12, 1985); 131 CoNG. REC. S11,603-10 (daily ed. Sept. 17, 1985) (Amendment No. 616 was adopted Sept. 17, 1985).

106. See 130 CoNG REC. H5863-70 (daily ed. June 14, 1984).

107. See supra note 105. 
twenty percent of the worker's salary would be deposited in the worker's home country, payable only upon the worker's timely return home. Employers would pay eleven percent of each worker's wages into a trust fund to cover administrative costs.

Foreign workers would be allowed to stay in one of the agricultural regions of the United States for up to thirty days while unemployed and seeking a job. Growers would be required to notify the Attorney General within seventy-two hours after a worker left their employ.

Under the plan, growers were required to conduct specific domestic worker recruitment efforts until foreign workers report to work. In addition, they were specifically required to provide summaries to the Attorney General of the prior year's recruitment efforts in order to participate in the program.

Growers were specifically required to provide such wages and working conditions as established by the Attorney General and their failure to do so would result in their disqualification from the program. It is critical to note that growers would have been required to provide the wages and conditions to workers comparable to those required under the $\mathrm{H}-2$ program, including payment of the adverse affect wage rate, the provision of housing, and the provision of workers' compensation or its equivalent.

Workers who were admitted into the program would be permitted a maximum length of stay of nine months. This did not mean that all workers would be admitted for nine months. The Attorney General would have the discretion to admit workers for any length of time up to nine months. In most instances workers would be admitted for a shorter time coinciding with peak harvest periods. An outside limit of nine months was chosen because in some regions the growing season for crops lasts nine months and longer. Those participating in the Seasonal Worker Program could not hire H-2 workers. In a somewhat surprising development, the Wilson amendment was adopted on the Senate floor amid one of the most controversial debates of S. $1200 . .^{108}$

In the 99th Congress, the issue of agricultural labor again dominated markup of the House bill by the House Judiciary Committee. The bill as ordered reported by that Committee included what was then known as the Schumer-Berman-Panetta amendment. ${ }^{109}$

108. See supra note 105.

109. H.R. 3810, 99th Cong., 1st Sess. (1986) (reported from the House Judiciary Committee, July 16, 1986); see H.R. REP. No. 682 pt. 1, 99th Cong., 2d Sess. (1986). 
Designed in large part as an alternative to a temporary worker program, the amendment was criticized by opponents during markup as creating a rolling legalization program because it gave foreign workers permanent residency immediately - with all the benefits of citizenship except the right to vote.

Radical legislative surgery on this approach was necessary in order to save the bill itself. As earlier explained, the version stitched together in the second week in October became the final product. The seasonal agricultural worker program signed into law in the 99th Congress grants temporary legal resident status to any alien who has performed at least ninety man-days in seasonal agricultural services from May 1, 1985 to May 1, 1986. ${ }^{110}$ This group would remain in this temporary status for a period of two years, at which time they could apply to adjust their status to that of a permanent resident. ${ }^{111}$

A second group of workers would be allowed to adjust to permanent residency after one year if it could be demonstrated that they worked ninety man-days in each of the last three years. This group would contain a numerical cap of 350,000 participants. ${ }^{112}$

Both before and during the application period, the bill provides for a temporary stay of exclusion or deportation for an apprehended alien who establishes a nonfrivolous case of eligibility until he is proven to be ineligible. ${ }^{113}$

\section{Replenishment Workers}

In the event a determination of agricultural labor shortage is established, the bill provides for replenishment of foreign workers for four years (1990-1993), contingent upon the certification by the Secretaries of Agriculture and Labor that a shortage of agricultural workers exists. The number to be admitted is determined by a specific formula of anticipated need minus supply of agricultural workers for that year. 114

The bill requires the Attorney General to admit for temporary resident status the number of aliens equal to the shortage number and requires their adjustment to permanent resident status after a threeyear period. ${ }^{115}$ The replenishment workers are required to work ninety man-days of seasonal agricultural services in each year for

(B)(ii)).

110. IRCA $\S 302(\mathrm{a}), 100$ Stat. at 3417 (amending/adding INA $\S 210(\mathrm{a})(1)$

111. Id. § 302(a), 100 Stat. at 3417-18 (amending/adding INA § 210(a)(2)(B)).

112. Id. \$302(a), 100 Stat. at 3418 (amending/adding INA $\$ 210(\mathrm{a})(2)(\mathrm{A})$, (c)).

113. Id. § 201(a), 100 Stat. at 3399 (amending/adding INA $\S 245 A(\mathrm{e})(1)$ ).

114. Id. § 303(a), 100 Stat. at 3422 (amending/adding INA § $210 \mathrm{~A}(\mathrm{a})$ ).

115 . Id. $\S 303(\mathrm{a}), 100$ Stat. at $3427-28$ (amending/adding INA $\S 210 A(\mathrm{c})(1)$,
(d)(5)(A)). 
three years to avoid deportation and to become eligible for permanent resident status. ${ }^{116}$

The Director of the Bureau of the Census is required to report annually to Congress on the estimated number of special agricultural workers. This section also disqualifies replenishment workers from receiving public benefits for a five-year period to the same extent as newly legalized aliens with the exception of eligibility under the Food Stamp Act and Housing Act. ${ }^{117}$

The bill requires employers to provide equal transportation arrangements and services to domestic workers as those provided to alien agricultural workers. It also makes applicable certain rights, remedies, and penalties under the Migrant and Seasonal Agricultural Worker Protection Act. ${ }^{118}$

Aliens admitted under this section may not be naturalized as United States citizens unless they have performed ninety man-days of seasonal agricultural services in each of five fiscal years. ${ }^{110}$

Section 304 establishes a Commission on Agricultural Workers composed of twelve members appointed by the President and Congress to review the impact of the special agricultural provisions on domestic farmworkers. ${ }^{120}$

\section{IMmigration Reform Legislation: The Future}

Continued immigration is vital to the health, wealth, and vitality of our nation. The contributions of immigrants in our history and in our midst are incalculable. Yet, to suggest that we should allow all who seek to come here carte blanche entry is to abdicate our sovereignty as a nation. To suggest that we can acommodate all the peoples of the world who desire to live here is unrealistic. Instead, we must define a policy that is compassionate, realistic and fair. To paraphrase the Select Commission, "we should seek to close the back door on illegal immigration so that the front door on legal immigration may remain open." 121

The passage of immigration reform legislation in the 99th Congress is by no means the final chapter on United States immigration policy. The full impact of this legislation will not be known for many

116. Id. § 303(a), 100 Stat. at 3428 (amending/adding INA § 210A(d)(5)(A)). (d)(6))

117. Id. § 303(a), 100 Stat. at 3427-28 (amending/adding INA § $210 \mathrm{~A}(\mathrm{~b})(3)$,

118. Id. § 303(a), 100 Stat. at 3430 (amending/adding INA § 210A(f)).

119. Id. $\S 303(\mathrm{a}), 100$ Stat. at 3428 (amending/adding INA $\S 210 \mathrm{~A}(\mathrm{~d})(5)(\mathrm{B})$ ).

120. Id. \& 304(a).

121. See Select Comm'N Final Report, supra note 12, at 2-3. 
years to come. Congress, however, cannot simply sit back and wait to see what happens. In addition to the many commissions already set up by the legislation, Congress will need to diligently exercise its oversight responsibilities with respect to this legislation and undoubtedly make technical changes and modifications to its many provisions. The next logical legislative step would be to address the many issues involving legal immigration. Particular consideration should be given to the value of "seed immigration," that is, those who bring special skills or economic benefits to the United States independent of the familial relationships for the most part required by the present preference system.

Yet, whatever future changes may be needed, it is clear that congressional and Administration support for passage of this immigration reform legislation in the 99th Congress reflects a heightened sense of urgency to address the current problems of illegal immigration in this country - problems which continue to grow each day.

This challenge can be demonstrated statistically by the increase in INS apprehensions of undocumented aliens. By the end of fiscal year 1986, 1.7 million undocumented aliens were apprehended in the United States - almost double that of the 1980 figure of 900,000 and an increase of one-third over the previous year. ${ }^{122}$ While many aliens are apprehended more than once, it is simply not possible to attribute this numerical increase to greater INS efficiency. Economic and civil strife south of our border juxtaposed with economic opportunity in the United States has generated enormous pressures to emigrate. According to a recent report by the GAO:

California is now absorbing more than one quarter of the legal immigrants
to the United States. Since 1975, California has been host to approximately
one third of the newly arriving refugees to this country. For the state as a
whole, almost 60 percent of the recent immigrants have come without
proper documentation. Recent immigrants have tended to settle in southern
California, and in Los Angeles in particular. Almost half of all post-1970
immigrants, documented and undocumented, live in Los Angeles County;
68 percent live in southern California.

The living conditions at the border continue to worsen as growing numbers live in poverty without access to minimal human requirements, such as adequate food and housing, because of their illegal status. Some argue that this situation parallels this country's early history with slavery. While history will be the ultimate judge, I believe there was simply no alternative to the immigration reform leg-

122. Apprehensions rose from 910,361 in the fiscal year 1980 , to a record $1,770,000$ in the fiscal year 1986. Schmidt, Detention of Aliens, 24 SAN DIEGo L. REV. 305, $306 \mathrm{n} .8$ (1987), in this issue.

123. General Accounting Office, Budget Issues: Immigration to the U.S. (1986).
Federal BudGet IMPACT 1984-1995, No. GAO-AFMD-86-53BR, Appendix II, 61 
islation. At a time when we had virtually lost control of our borders, a growing sub rosa population was arising within our midst. As a sovereign and compassionate nation, this situation was entirely untenable. From the standpoint of both American workers as well as those sentenced to "third world" living conditions within our borders, something needed to be done.

No one will attribute divine inspiration to the immigration reform bill. Yet, the alternative of doing nothing would have evidenced the lack of any inspiration at all on the part of our nation's leadership.

The immigration reform bill was certainly a compromise. None of its supporters consider this the perfect solution. While many of its individual provisions would not have garnered majority support alone, the bill as a package brought together a coalition of individuals with diverse ideological and political backgrounds. And that unusual, often tenuous coalition added up to a majority in the Congress. While this posed an unacceptable threat to the orthodoxy of some members, it should not detract from the significance of this accomplishment. All things considered, in the give and take of the legislative process, Congress finally produced an immigration bill that is in the national interest. 


$$
\text { • }
$$

